\title{
Redescription of two species of Aphidiinae (Hymenoptera: Braconidae) from high mountain areas of south-eastern Europe, with biological and biogeographical notes on co-occurring guild members
}

\author{
Željko Tomanović*, Nickolas G. Kavallieratos, Petr Starý, Vladimir Žikić, \\ Vladimir Tomić \& Luka Lučić
}

Tomanović, Ž., Kavallieratos, N. G., Starý, P., Žikić, V., Tomić, V. \& Lučić, L. 2007: Redescription of two species of Aphidiinae (Hymenoptera: Braconidae) from high mountain areas of south-eastern Europe, with biological and biogeographical notes on co-occurring guild members. - Entomol. Fennica 18: 36-45.

Praon spinosum Mackauer, 1959 reared from Thripsaphis verrucosa Gillette, 1917 on Carex nigra and Diaeretellus macrocarpus Mackauer, 1961 reared from the conspecific aphid on Carex rostrata association from Mt. Durmitor Biosphere Reserve in Serbia and Montenegro are redescribed, diagnosed and illustrated with photographs from SEM and line drawings. The taxonomic position of P. spinosum within the genus Praon is discussed. Furthermore, some rare and endemic aphid - aphid-parasitoid associations from high-montane areas of southeastern Europe are reviewed and their distribution and origin is discussed.

Ž. Tomanović (*corresponding author), Institute of Zoology, Faculty of Biology, University of Belgrade, Studentski trg 16, 11000 Belgrade, Serbia; Tel: +38111638890,e-mail: ztoman@bf.bio.bg.ac.yu

N. G. Kavallieratos, Benaki Phytopathological Institute, Department of Entomology and Agricultural Zoology, Laboratory of Agricultural Entomology, 8 Stefanou Delta str., Kifissia, 14561, Attica, Greece; e-mail: nick_kaval @hotmail.com

P. Starý, Institute of Entomology, Academy of Sciences of the Czech Republic, Branišovská 31, 37005 České Budějovicé, Czech Republic; e-mail: stary@entu. cas.cz

V. Žikić, Institute of Zoology, Faculty of Biology, University of Belgrade, Studentski trg 16, 11000 Belgrade, Serbia; e-mail:vzikic@yahoo.com $V$. Tomić, Institute of Zoology, Faculty of Biology, University of Belgrade, Studentskitrg 16, 11000 Belgrade, Serbia; e-mail:vtomic@bf.bio.bg.ac.yu L. Lučić, Institute of Zoology, Faculty of Biology, University of Belgrade, Studentskitrg 16,11000 Belgrade,Serbia; e-mail: luka@bf.bio.bg.ac.yu

Received 19 July 2005, accepted 29 March 2006 


\section{Introduction}

During the research on aphid parasitoid guilds in swampy habitats on Mt. Durmitor in Serbia and Montenegro, specimens of Thripsaphis verru$\cos a$ Gillette, 1917/Carex spp. associations were sampled and two parasitoid species, Praon spinosum Mackauer, 1959 and Diaeretellus macrocarpus Mackauer, 1961, were reared. These species represent an isolated parasitoid guild associated with Carex spp. in high-montane areas (Mackauer 1959, 1961, Mackauer \& Starý 1967). D. macrocarpus and $P$. spinosum have rarely been collected in the Palaearctic, but are widely spread from Finland to Serbia and Montenegro (Mackauer 1961, Starý 1966, Achterberg 2004). Furthermore, the original description of $D$. macrocarpus by Mackauer (1961) has become out-dated and it is not illustrated. Similarly, the description of $P$. spinosum was based only on one female specimen reared from Thripsaphis sp. by Börner in Germany in 1942.

$P$. spinosum and D. macrocarpus are redescribed here, and some rare and endemic aphid - aphid parasitoid associations from highmontane areas of south-eastern Europe are reviewed with particular reference to their distributions and origins.

\section{Material and methods}

Samples from Carex rostrata (L.) and Carex nigra (L.) with both live and mummified aphids were collected from Valovito Jezero $(1700 \mathrm{~m})$ and Modro Jezero $(1600 \mathrm{~m})$ on Mt. Durmitor Biosphere Reserve (Serbia and Montenegro). Each sample was placed separately in a plastic bag, which was next brought to the laboratory where aphids were identified. Live aphids were preserved in 2:1 90\% ethyl alcohol and 75\% lactic acid (Eastop \& van Emden 1972). Mummies, each still attached to a small piece of leaf, were placed separately in small plastic boxes, which were put inside a growth cabinet. There was a circular opening covered with muslin for ventilation on the lid of each box in order to maintain inside the boxes conditions similar to those existing in the growth cabinet $\left(22.5^{\circ} \mathrm{C}, 65 \%\right.$ relative humidity, 16:8 L:D photoperiod) (Kavallieratos et al.
2001, Trdan 2002). External structure of the emerged parasitoids was studied using an OLYMPUS SZX 9 stereomicroscope. Females of $P$. spinosum and D. macrocarpus were gold coated and examined using a Jeol JSM $-6460 \mathrm{LV}$ scanning electron microscope. The terminology used in this paper follows Huber and Sharkey (1993) and Kavallieratos et al. (2001).

We redescribed $P$. spinosum and $D$. macrocarpus on the basis of our specimens reared from Thripsaphis verrucosa on C. nigra and C. rostrata.

\section{Results}

\subsection{Redescription of Praon spinosum Mackauer, 1959 (Figs. 1, 2a, b)}

Holotype +. Germany, Tschdf., 11.VIII.1942, reared from Thripsaphis sp., leg. C. Börner. Deposition: Deutsches Entomol. Institut, ex Coll. Börner.

Additional material. Five females and four males, Serbia and Montenegro, Mt Durmitor Modro Jezero, 21.VII.2004, reared from $T$. verrucosa on C. nigra, leg. $\breve{Z}$. Tomanović and V. Žikić (hereafter ŽT and VŽ).

Female. Head. Eyes oval, sparsely haired (Fig. 1a). Malar space equal to about 0.20 times the longitudinal eye diameter. Clypeus oval, with 19-22 long setae. Face with sparse setae. Tentorial index (tentoriocular line/ intertentorial line) $0.17-0.20$. Head almost 1.2 times wider than mesoscutum. Maxillary palp 4-segmented, labial palp 3-segmented. Antennae 15-16-segmented, filiform, with semi-erect and adpressed setae which are shorter than the diameter of the segments. Flagellomere 1 (Fig. 1b) 4.0-4.5 times as long as median width. $F_{2}$ (Fig. 1 b) about 3.0 times as long as median width. $\mathrm{F}_{1}$ without longitudinal placodes and $F_{2}$ without or with one longitudinal placode (Fig. 1b).

Mesosoma. Mesonotum (Fig. 1c) with central lobe densely covered with long setae. Lateral lobes of mesonotum sparsely setaceous (Fig. 1c). Notaulices deep and distinct throughout. Propodeum smooth, densely setaceous except in the small central area (Fig. 1d).

Forewing. Pterostigma elongated, about 4.5 


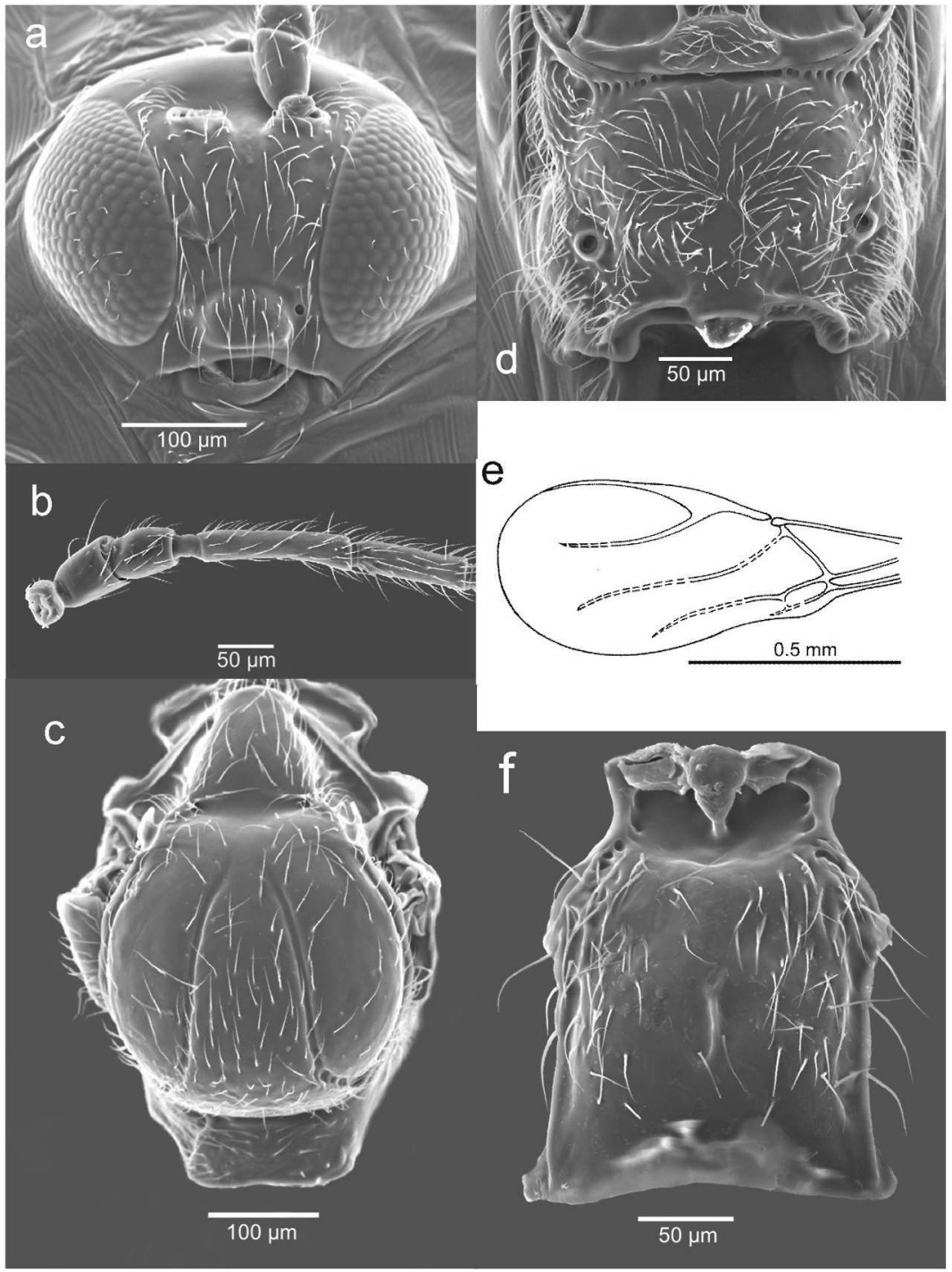

Fig.1. Praon spinosum Mackauer, 1959, female. - a. Head, anterior aspect. $-b$. Antennae, basal part $\left(\mathrm{F}_{1}\right.$ and $F_{2}$ ). $-c$. Mesonotum, dorsal aspect. - d. Propodeum, dorsal aspect. - e. Forewing. $-f$. Petiole, dorsal aspect. times as long as wide and subequal to distal abscissa of R1 (=metacarpus) (Pterostigma length / $\mathrm{R} 1$ length $=0.90-1.00$ ) (Fig. 1e). Vein Rs about 0.85 times as long as pterostigma and about 0.80 times as long as distal abscissa of R1. Vein $\mathrm{m}-\mathrm{cu}$ is completely effaced. $R s+M$ vein colourless in basal part and coloured in distal part (Fig. 1e).

Metasoma. Petiole (= tergite 1) about 1.4 times as long as wide at level of spiracles with long setae at both sides (Fig. 1f). Ovipositor sheath moderately elongate with slightly concave dorsal part. Apex round, with two conical apical spines (Figs 2a, b).

Colouration. Head black to brown. Scape, pedicel and $F_{1}$ yellowish, except distal part of $F_{1}$ brownish, remaining part of antenna black to brown. Mouthparts brownish. Petiole brown to black. Legs yellow with dark apices. Metasomal tergum 2 and 3 brown to black. Remaining body parts black. Cocoon whitish.

Body length. 2.6-2.8 mm.

Male. Antenna 18-19-segmented. $\mathrm{F}_{1}$ about 3.0 times as long as wide. Petiole subquadrate. Head black. Mouthparts brownish. Scape and pedicel brownish. Basal ring of $F_{1}$ yellow, remaining part of antenna brown.

Body length. 2.3-2.5 mm.

Hyperparasitoids. Dendrocerus bifoveatus 
Fig. 2. P. spinosum, female. - a. Ovipositor sheath, lateral aspect. - b. Ovipositor sheath, lateral aspect (enlarged); Praon necans Mackauer, 1959, female. - c. Petiole, dorsal aspect. $-d$. Forewing.
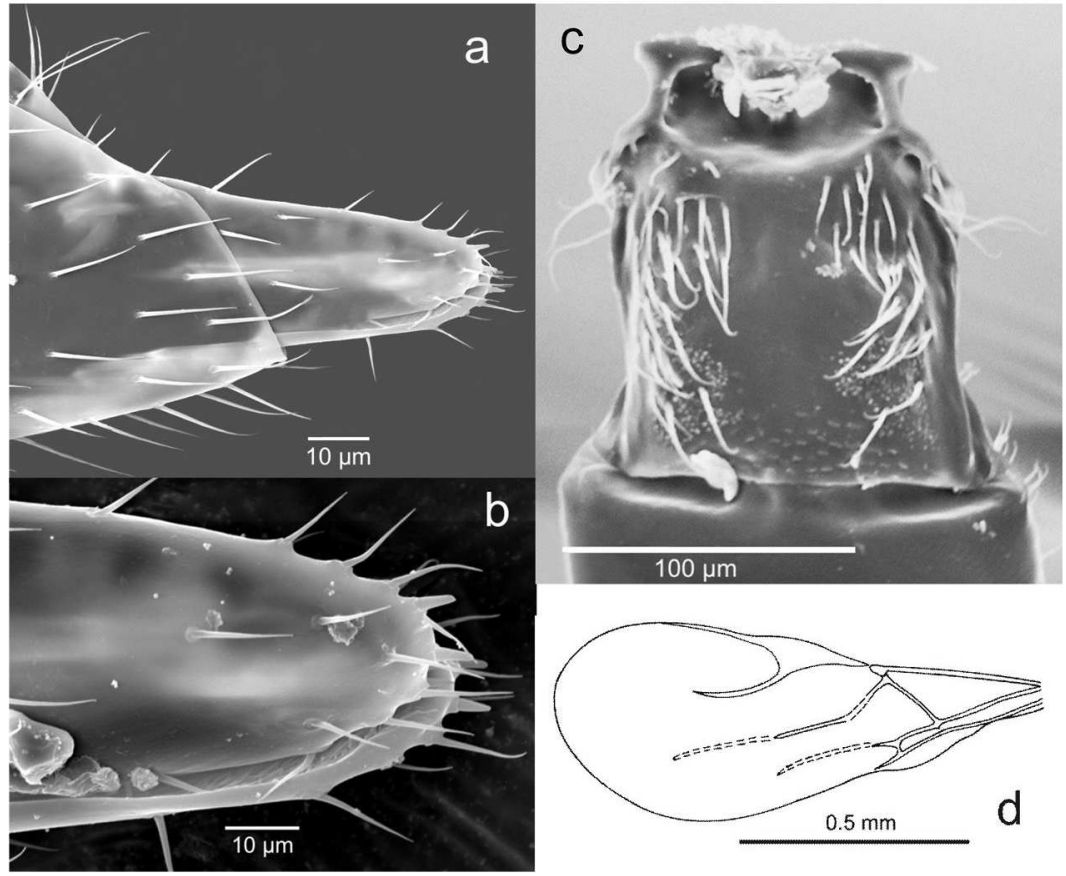

(Kieffer, 1907) (4 specimens) (Hymenoptera: Megaspilidae), Asaphes suspensus (11 specimens) (Nees, 1834) (Hymenoptera: Pteromalidae), Syrphophagus sp. (2 specimens) (Hymenoptera: Encyrtidae) - Serbia and Montenegro, Mt Durmitor - Modro Jezero, 21.VII. 2004, reared from T. verrucosa on C. nigra, leg. $\check{Z} \mathrm{~T}$ and VŽ. Specimens are deposited in collection of Institute of Zoology, Faculty of Biology, University of Belgrade, Serbia.

Diagnosis. P. spinosum belongs to the "Parapraon" species group which is characterized by the absence of vein m-cu in the forewing. $P$. spinosum resembles Praon necans (Mackauer 1959) but it is immediately distinguished from it by the ratio of length to width at the level of the spiracles of the petiole (=tergite I) [approximately 1.4 in $P$. spinosum (Fig. 1f) compared with 1.0-1.1 in $P$. necans (Fig. 2c)] and the length and width of the pterostigma [approximately 4.5 as long as wide in $P$. spinosum (Fig. 1e) compared with 3.2-3.9 in $P$. necans (Fig. 2d)]. For the above comparisons three series of $P$. necans reared from Rhopalosiphum nymphaeae (L., 1761) in France, Czech Republic and Serbia and Montenegro were used. Furthermore, $P$. spinosum appears to be a specialized parasitoid of T. verrucosa whereas $P$. necans parasitizes $R$. nymphaeae in the Palaearctic (Mackauer 1959, Starý 1966).

\subsection{Redescription Diaeretellus macrocarpus Mackauer, 1961 (Figs. 3-4)}

Holotype 9. Germany, Wildseemoor, 26.VII. 1960, reared from Bacillaphis sp. on Carex sp., leg. R. Van den Bosch, M. Mackauer and F. Stroman. Deposited in coll. Mackauer (Vancouver, Canada).

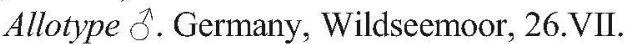
1960, reared from Bacillaphis sp. on Carex sp., leg. R. Van den Bosch, M. Mackauer and F. Stroman. Deposited in coll. Mackauer (Vancouver, Canada).

Paratypes. 19 and $3 \hat{\partial}$, same data as holotype.

Additional material. 4q9, Germany, Windgefäll-Weiher, Schwarzwald, 28.VII.1960, reared from Bacillaphis sp. on Carex sp., leg. R. Van den Bosch, M. Mackauer and F. Stroman; 3우, Germany, Tieringen, Schwäbische Alb, 31.VII.1960, reared from Thripsaphis sp. on Carex sp., leg. R. Van den Bosch; 19, Sweden, Vrml. Karlskoga, 13.VII.1954, reared from 


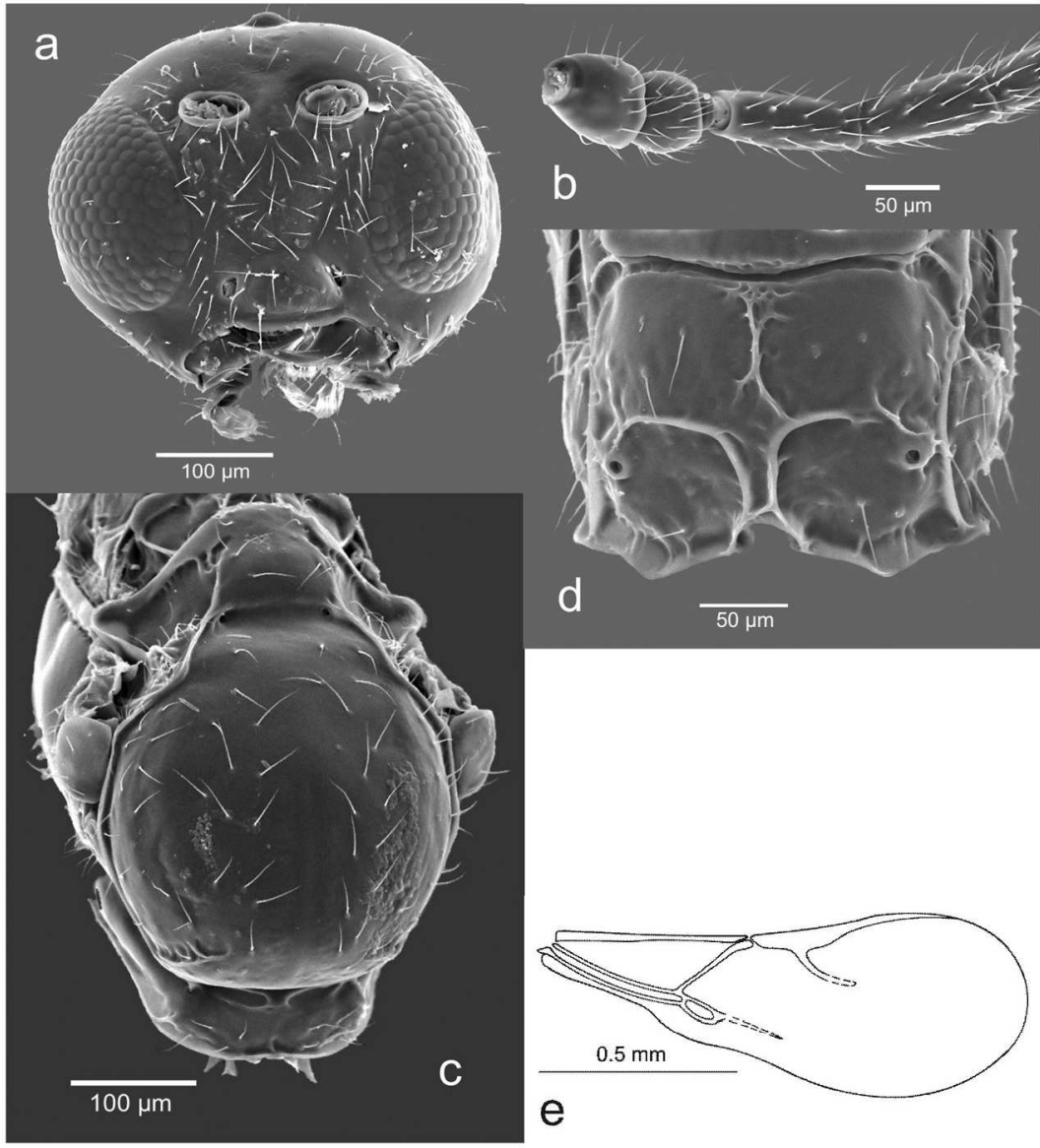

Fig. 3. Diaeretellus macrocarpus, Mackauer, 1961, female. - a. Head, anterior aspect. - b. Antennae, basal part $\left(F_{1}\right.$ and $\left.F_{2}\right)$. -c. Mesonotum, dorsal aspect. $-d$. Propodeum, dorsal aspect. $-e$. Forewing.
Iziphya ingegardae Hille Ris Lambers on Carex sp., leg. F. Ossiannilsson; 1 and $1 \%$, Serbia and Montenegro, Mt Durmitor - Valovito Jezero, 3.VII.2002, reared from $T$. verrucosa on $C$. rostrata, leg. N. G. Kavallieratos (hereafter NK) and $\check{Z T}$; $1 \delta$, Serbia and Montenegro, Mt Durmitor - Valovito Jezero, 20.VII.2004, reared from $T$. verrucosa on C. rostrata, leg. $\check{T} \mathrm{~T}$ and VŽ; $29+$ and $3 \hat{\delta} \hat{\delta}$, Serbia and Montenegro, Mt Durmitor-Modro Jezero, 21.VII.2004, reared from $T$. verrucosa on C. nigra, leg. ŽT and VŽ.

Female. Head. Eyes oval (Fig. 3a). Malar space equal to 0.25 longitudinal eye diameter. Clypeus oval, with 5-8 long setae (Fig. 3a). Tentorial index about 0.55 . Maxillary palp 3 -segmented, labial palp 1-segmented. Head 1.2-1.3 times wider than mesoscutum. Antennae 14-segmented, moderately thickened at apex, with semierect and adpressed setae which are shorter than the diameter of the segments. $\mathrm{F}_{1}$ and $\mathrm{F}_{2} 3.3-$
3.4 times as long as wide, without longitudinal placodes. $F_{1}$ equal to $F_{2}$ (Fig. 3b).

Mesosoma. Mesonotum with notaulices distinct in the fore part, slightly crenulated, with two rows of setae. Notaulices effaced on the disc (Fig. $3 \mathrm{c}$ ). Propodeum areolated, with 5-6 setae on its upper and 4-5 setae on its lower areola. Areola narrow and pentagonal (Fig. 3d).

Forewing. Pterotigma 4.3-4.5 times as long as wide. Distal abscissa of R1 (-metacarpus) equal to pterostigma (Fig. 3e).

Metasoma. Petiole 2.7-2.8 times as long as wide at spiracles, with $7-8$ costulae on its anterolateral area, with rugose mediodorsal part and weakly prominent mediodorsal carina (Fig. 4a). Ovipositor sheath linear in its dorsal margin (Figs. 4b, c).

Colouration. Head black. Mouthparts brownish. Scape and pedicel brownish. $\mathrm{F}_{1}$ with narrow yellow ring at the base, remaining part of anten- 


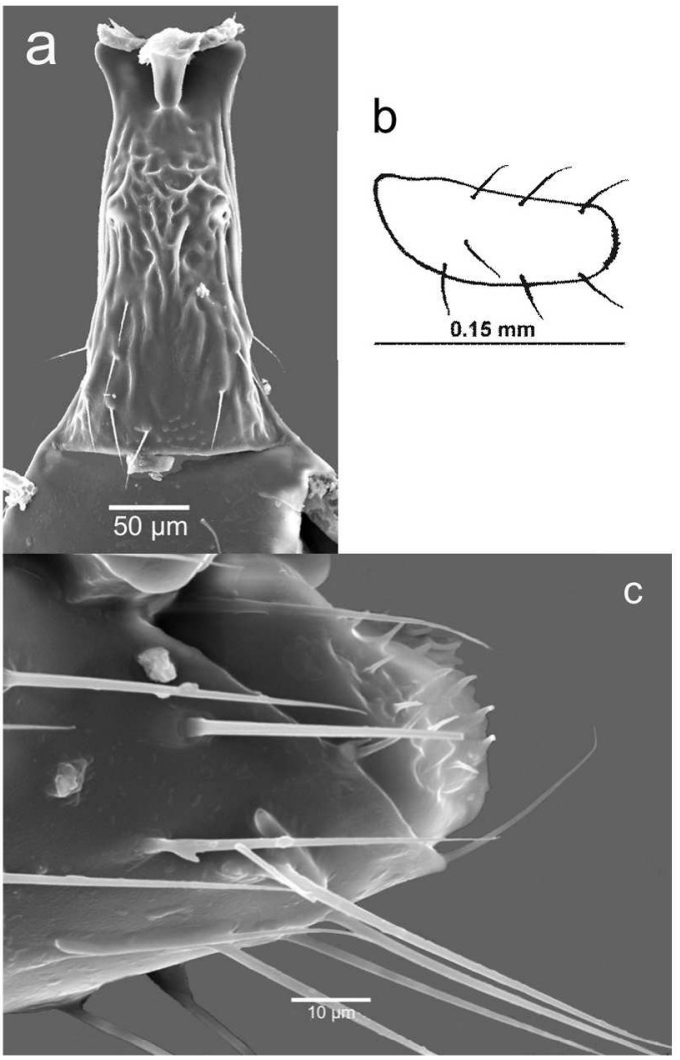

Fig. 4. D. macrocarpus, female. - a. Petiole, dorsal aspect. - b. Ovipositor sheath, lateral aspect. - c. Ovipositor sheath, lateral aspect (enlarged).

nae brown. Petiole and metasomal tergum 2 brown to black. Legs brownish with dark apices. Rest of body black.

Body length. 2.5-2.8 mm.

Male. Antennae 16-segmented, moderately thickened at apex, with semierect and adpressed setae which are shorter than the diameter of the segments. Body generally black except brown mouthparts and legs.

Hyperparasitoids. Dendrocerus bifoveatus ( 2 specimens) (Kieffer, 1907) (Hymenoptera: Mechaspilidae) - Serbia and Montenegro, Mt Durmitor - Valovito Jezero, 3.VII.2002, reared from $T$. verrucosa on $C$. rostrata, leg. NK and ŽT; Asaphes vulgaris (Walker, 1834) (5 specimens) (Hymenoptera: Pteromalidae) - Serbia and Montenegro, Mt Durmitor-Modro Jezero, 21.VII.2004, reared from $T$. verrucosa on $C$. nigra, leg. ŽT and VŽ. Specimens are deposited in collection of Institute of Zoology, Faculty of
Biology, University of Belgrade, Serbia.

Remarks. D. macrocarpus specimens reared from $T$. verrucosa had longer $\mathrm{F}_{1}$ than the type specimens [3.3-3.4 times as long as median width, compared with 'Segment 3 mindestens 2.5-mal so lang wie dick...' (Mackauer 1961)]. Males with 16-segmented antennae instead of the $17-18$ in the type specimens.

\subsection{Some rare high montane aphid parasitoid species in south-eastern Europe}

All specimens collected in Serbia and Montenegro are deposited in the collection of Institute of Zoology, Faculty of Biology, University of Belgrade, Serbia. Specimens collected in Greece are deposited in the collection of Laboratory of Agricultural Zoology and Entomology, Agricultural University of Athens (Greece).

Aphidius galii Tomanović \& Kavallieratos, 2002

Linosiphon sp. on Galium lucidum (699, 533), Mt Durmitor-Crno jezero, 30.VI.2001, leg. ŽT,

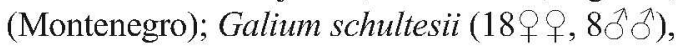
Mt Durmitor-Crno jezero, 30.VI.2002, Mt Durmitor-Jezerska gora, 1.VII.2002, leg. ŽT, (Montenegro).

Aphidius linosiphonis Tomanović \& Starý, 2001

Linosiphon galiophagum (Wimshurst) on Galium sylvaticum $(5+q, 11 \hat{\jmath})$, Mt TaraDerventa Canyon, 31.V.1998, leg. ŽT, (Serbia).

Aphidius montenegrinus Tomanović \& Kavallieratos, 2004

Acyrthosiphon daphnidis Ilharco, 1994 on Daphne alpina (5ㅇ, $6 \lesssim \delta)$, Mt DurmitorZabojsko jezero, 1.VIII.2002, leg. NK and ŽT, (Montenegro).

Aphidius sussi Pennacchio \& Tremblay, 1988

Delphiniobium junackiamum Karsch. on

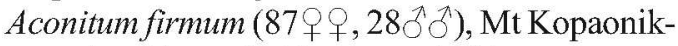
Metođe, 03.VII.2000, 7.VIII.2000, Mt Kopaonik-Samokovka, 9.VII.2000, 6.VIII.2000, 25.VIII.2000, Mt Kopaonik-Marine vode, 6.VIII.2000, Mt Kopaonik-Konaci, 23.VIII. 2000, leg. ŽT, (Serbia); A. toxicum ssp. bosniacum $(61+q, 35 \delta \delta)$, Mt Durmitor-Crno jezero, 
2.VII.1998, 15.VIII.1998, 13.VII.2000, 19.VII. 2000, 30.VI.2002, 4.VII.2002, leg. ŽT, (Serbia), Mt Kopaonik-Metođe, 18.VIII.1998, 20.VII. 1999, leg. O.Petrović-Obradović, (Serbia), Biogradska gora, 26.VII.2001, Mt DurmitorSušica, 2.VII.2002, leg. ŽT, (Montenegro); Aconitum napellus (4우), Central Macedonia, 21.VI.2002, leg. N. Emmanouel, (Greece); Italy - Pennacchio and Tremblay (1988).

Aphidius sp.

Macrosiphum daphnidis Börner on Daphne oleoides $\left(12+9\right.$, $\left.1 \delta^{\Uparrow}\right)$, Mt. Tymphi, Ioannina, Western Greece, 17. VII. 2003, 3.VII. 2004, 18.VII. 2004, leg. NK and ŽT (Greece).

Ephedrus blattnyi Starý, 1973

Pterocomma rufipes (Hartig) on Salix retusa (1ㅇ, 1ठ), Durmitor-Mali Međed, 14.VII. 2000, leg. O. Petrović Obradović, Durmitor-Mali Međed, 18.VII.2000, leg. S. Tomanović, (Montenegro); Slovakia - Starý and Leclant (1973).

Diaeretellus palustris Starý, 1971

Rhopalosiphum nymphaeae Linnaeus on Ranunculus aquatilis (2えð), Mt Vlasina, 22.VII.1990, leg. O. Petrović Obradović, (Serbia); Germany - Starý (1971).

Lysiphlebus balcanicus Starý, 1998

Aphis psammophila Scelegiewicz on Jasione heldreichii (6우), Mt Vlasina, 21.VII.1990, leg. O. Petrović Obradović, 30.VII.1996, leg. ŽT, (Serbia); Spain - Sanchis et al. (1999).

Monoctonus leclanti Tomanović \& Starý, 2002

Delphiniobium junackianum Karsch. on Aconitum pentheri (19), Mt Kopaonik-Metođe, 7.VIII.2000, leg. ŽT, (Serbia); A. toxicum ssp. bosniacum (699, 1§), Mt Kopaonik-Metođe, 18.VIII.1998, 20.VII.1999, leg. O. Petrović Obradović, (Serbia), Mt Durmitor-Crno jezero, 15.VIII.1997, leg. O. Petrović Obradović, 19.VII.2000, Mt Durmitor-Sušica Canyon, 2.VII.2002, leg. ŽT, (Montenegro).

Praon retusae Tomanović \& Kavallieratos, 2002

Acyrthosiphon cf. malvae (Mosley) on Salix retusa (1, 1 1 ), Mt Durmitor-Mali Međed, 6.VII.1998, 14.VII.2000, (Montenegro).
Trioxys chaetosiphonis Starý, 1971

Longicaudus trirhodus (Walker) on Thalictrum aquilegifolium (29ㅇ), Mt KopaonikSamokovska reka, 8.VII.2000 leg. ŽT, (Serbia); France - Starý et al. (1971).

Trioxys galiobii Starý, 1974

Myzus langei Börner on Galium lucidum (19), Zlatarsko jezero, 11.VII.1991 leg. O. Petrović Obradović, (Serbia); Czech Republic - Starý (1974).

\subsection{Some new high montane aphid parasitoid associations from south-eastern Europe}

Aphidius avenae Haliday, 1834

Acyrthosiphon malvae (Mosley) on Achilea tanacetifolia (3q9), Mt Šara-Livadačko jezero, 24.VII.1995 leg. O. Petrović Obradović, (Serbia); Acyrthosiphon cf. malvae (Mosley) on Salix

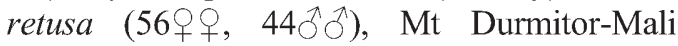
Međed, 6.VII.1998, 18.VII.2000, Mt DurmitorLedena pećina, 17.VII.2000, leg. ŽT, (Montenegro).

Aphidius ervi Haliday, 1834

Macrosiphum daphnidis Börner on Daphne oleoides (4우), Mt Tymphi, Ioannina, Western Greece, 3.VII.2004, leg. NK (Greece); Macrosiphum cholodkovskyi (Mordvilko) on Filipendula ulmaria, $(9 q 9,9 \delta \hat{\sigma})$, Mt DurmitorCrno jezero, 30.VI.2001, leg. ŽT, (Montenegro).

Aphidius microlophii Pennacchio \& Tremblay, 1986

Wahlgreniella ossiannilssoni Hille Ris Lambers on Arctostaphylus uva ursi $(1099,6 \AA \precsim)$, Mt Durmitor-Škrčka jezera, 7.VIII. 2005, leg. VŽ and ŽT, (Montenegro).

Aphidius urticae Haliday, 1834

Acyrthosiphon daphnidis Ilharco on Daphne alpina (3우), Mt Durmitor-Zabojsko jezero, 01.VII.2002, leg. ŽT, (Montenegro).

Binodoxys acalephae (Marshall, 1896)

Aphis myrsinitidis Petrović \& Leclant on 
Euphorbia myrsinites (6우, 7ठう), Mt Zlatar, 11.VII.1991, (Serbia), Mt Durmitor-Crno jezero, 27.VIII.1991, leg. O. Petrović Obradović, (Montenegro); Uhlmania singularis (Börner) on Asperula cynanchica (2q9), Žabljak, 09.VII. 1995, leg. O. Petrović Obradović, (Montenegro).

Binodoxys brevicornis (Haliday, 1833)

Uhlmania singularis (Börner) on Asperula longifolia, Mt Durmitor-Crno jezero, 30.VI. 2002, leg. ŽT, (Montenegro).

Diaeretiella rapae (M'Intosh, 1855)

Aphis cadiva Walker on Silene vulgaris $(2 \hat{\jmath})$, Mt Durmitor-Zminje jezero, 23.VIII.1990, leg. O. Petrović Obradović, (Montenegro); Pseudobrevicoryne leclanti Petrović and Remaudičrč on Arabis alpina (3우), Mt Durmitor-Crno jezero, 15.VIII.1997, leg. O. Petrović Obradović, (Montenegro).

Ephedrus plagiator (Nees, 1811)

Aphis salicariae Koch on Epilobium angustifolium (3q), Kopaonik-Samokovska reka, 6.VIII.2000, leg. ŽT, (Serbia); Macrosiphum cholodkovskyi (Mordvilko) on Filipendula ulmaria (1q, 1ठ), Mt Kopaonik-Marine vode, 8.VII.2000, leg. ŽT, (Serbia).

Lysaphidus viaticus Sedlag, 1968

Pleotrichophorus duponti Hille Ris Lambers on Achillea millefolium (3qq), Mt DurmitorZminje jezero, 17.VIII.1997, leg. O. Petrović Obradović, (Montenegro).

Lysiphlebus fabarum (Marshall, 1896)

Aphis carlinae (Börner) on Carlina acaulis (2q9), Mt Šara-Ošljak, 4.VII.1995, leg. O. Petrović Obradović, (Serbia).

Monoctonus crepidis (Haliday, 1834)

Hyperomyzus hieracii (Börner) on Hieracium sp. (19), Mt Durmitor-Zminje jezero, 13.VII.2000, leg. ŽT, (Montenegro).

Monoctonus nervosus (Haliday, 1833)

Acyrthosiphon cf. malvae (Mosley) on Salix retusa $(390,11 \delta \delta)$, Mt Durmitor-Mali Međed, 6.VII.1998, 14.VII.2000, Mt Durmitor-Ledena pećina, 17.VII.2000, leg. ŽT, (Montenegro).
Praon longicorne Marshall, 1891

Macrosiphum cholodkovskyi (Mordvilko) on Filipendula ulmaria (5우), Mt Durmitor-Crno jezero, 30.VI.2001, 4.VII.2002, leg. ŽT, (Montenegro).

\section{Discussion}

\subsection{Habitats and distribution}

Both $P$. spinosum and D. macrocarpus were collected in swampy montane habitats and reared from $T$. verrucosal Carex spp. associations. $T$. verrucosa lives on several Carex spp. (Heie 1982 ) in very specific microhabitats, between the stem and the lower leaves just at the water surface, where there is very high humidity. A comparison of the habitats of the two species indicates that they tend to be associated with montane swamps and moors in Europe (Mackauer 1961, Starý 1966).

\subsection{Biodiversity and biogeography}

High montane areas in south-eastern Europe represent a very important centre of aphidiine diversity (Kavallieratos et al. 2004). This is due to great plant and habitat diversities and dynamic historical processes (Matvejev \& Puncer 1989), with the glacial and postglacial history of this region being very complex. Colder climate and glacial phenomena in south-eastern Europe were less expressed than in Central and Northern Europe. This resulted in a relative richness of flora, which was not reduced by the influence of glacial periods as it was in Central and Northern Europe. This is one of the main reasons for the significant presence of Tertiary relics and endemism of plants and associated insects in this area. We revealed many new and rare aphid parasitoid species and host associations from high mountains over the period 1996-2004 (Starý et al. 1998, Kavallieratos \& Tomanović 2001, Tomanović \& Kavallieratos 2002, Tomanović et al. 2002, 2003, 2004, Kavallieratos et al. 2004, 2005). Some of the aphidiines as members of new host associations have economical importance as biocontrol 
agents of pest aphids [A. ervi, A. avenae, Ephedrus plagiator (Nees, 1811), Diaeretiella rapae (M'Intosh, 1855), Lysiphlebus fabarum (Marshall, 1896)].

Biogeographically, high montane associations and species are characterized by an insular type of distribution. In spite of the fact that their host aphids have much broader distribution, some aphidiine species are restricted to specific high montane microhabitats. Based on the known distribution of aphidiine wasps, we recognize two patterns of their distribution: the Eastern-Western and the Southern-Northern. The EasternWestern pattern distribution indicates an ancient Mediterranean origin of aphidiinae species and associations (L. balcanicus, M. leclanti, A. sussi, P. retusae, Aphidius galii Tomanović \& Kavallieratos, 2002, Aphidius linosiphonis Tomanović \& Starý, 2001, A. montenegrinus). The Southern-Northern distribution pattern presupposes a glacial origin of the aphidiine species and associations (E. blattnyi Starý, Diaeretellus palustris Starý, 1960, D. macrocarpus, P. spinosum, Trioxys chaetosiphonis Starý, 1971 and Trioxys galiobii Starý, 1974).

\subsection{Taxonomy}

P. spinosum belongs to the "Parapraon" species group. Starý (1983) established a new genus Parapraon mainly based on the lack of the recurrent (m-cu) vein in the forewing. However, Johnson (1987) pointed out the great variability of character states of $\mathrm{m}$-cu vein and consequently synonymized Parapraon with Praon. Later on, molecular phylogenetic studies did not find any support for the generic status of Parapraon (Kambhampati et al. 2000). According to Kavallieratos et al. (2005) the "Parapraon" species group is monophyletic inside the genus Praon. All studied European "Parapraon" [Praon necans, Mackauer, 1959, Praon gallicum Starý, 1971, P. retusae and Praon exsoletum (Nees, 1811)] and P. spinosum] share the following synapomorphies: absent or significantly reduced vein $\mathrm{m}-\mathrm{cu}$, elongated ovipositor sheath, two conical apical spines on the ovipositor sheath and large hairless areas on the lateral lobes of the mesonotum.
The genus Diaeretellus is closely related to the Aphidius Nees, 1819, Euaphidius Mackauer, 1961, Diaeretiella Starý, 1960 and Diaeretus Förster, 1862 based on morphology, but the phylogenetic relationships and taxonomic status of these genera need further investigation.

Acknowledgements. The research was supported by the Conservation and Environmental Grant of Ford Motor Company (2004) (Grand Motors Belgrade), the Grants 143006 and 143053 (The Ministry of Science and Environmental Protection of the Republic of Serbia), the Grant S5007102 (Grant Agency, Academy of Sciences of the Czech Republic) and by the Entomology Institute Project Z50070508 (Academy of Sciences of the Czech Republic). We wish to thank Dr Olivera Petrović Obradović (Faculty of Agriculture, University of Belgrade) for the identification of aphids and Dr Aleksandar Stojanović (Belgrade Natural History Museum) for the identification of hyperparasitoids.

\section{References}

van Achterberg, C. 2004: Fauna Europaea: Braconidae. In: van Achterberg C. (ed.), Fauna Europaea: Hymenoptera: Symphyta + Ichneumonoidea. Fauna Europaea version 1.1. [www document] URL http:// www.faunaeur.org.

Eastop, V. F. \& van Emden, H. F. 1972: The insect material. - In van Emden, H. F. (ed.), Aphid technology. Academic Press), London. 45 pp.

Heie, O. E. 1982: The Aphidoidea (Hemiptera) of Fennoscandia and Denmark II. The family Drepanosiphidae. - Fauna Entomol. Scand. 11: 1-176 pp.

Huber, J. T. \& Sharkey, M. J. 1993: Structure. - In Goulet, H, \& Huber, J T. (eds), Hymenoptera of the world: An Identification Guide to Families: 13-59. Publication 1894/E (Ottawa, Ontario: Research Branch, Agriculture Canada), pp. 668.

Johnson, J. W. 1987: A revision of the species of Praon Haliday in North America, North of Mexico (Hymenoptera: Aphidiidae). - The Canadian Entomologist 119: 999-1025.

Kambhampati, S., Volkl, W. \& Mackauer M., 2000: Phylogenetic relationships among genera of Aphidiinae (Hymenoptera: Braconidae) based on DNA sequence of the mitochondrial 16S rRNA gene. - Systematic Entomol. 25: 437-445.

Kavallieratos, N. G. \& Tomanović, Ž. 2001: Some rare and endemic aphid parasitoid species (Hymenoptera: Braconidae: Aphidiinae) from the Balcan Peninsula. - Acta Entomol. Serbica 6: 121-129.

Kavallieratos, N. G., Lykouressis, D. P., Sarlis, G. P., Stathas, G. J., Sanchis Segovia, A. \& Athanassiou, C. G. 2001: The Aphidiinae (Hymenoptera: Ichneumonoidea: Braconidae) of Greece. - Phytoparasitica 29: 306-340. 
Kavallieratos, N. G., Tomanović, Ž, Starý, P., Athanassiou, C. G., Sarlis, G. P., Petrović, O., Niketić, M. \& Anagnou-Veroniki, M. 2004: A survey of aphid parasitoids (Hymenoptera: Braconidae: Aphidiinae) of Southeastern Europe and their aphid-plant associations. - Applied Entomol. Zool. 39: 527-563.

Kavallieratos, N. G., Tomanović, Ž., Starý, P., Athanassiou, C. G., Fasseas, C., Petrović, O., Stanisavljević, L. Ž. \& Anagnou-Veroniki, M. 2005: Praon Haliday (Hymenoptera: Braconidae: Aphidiinae) of Southeastern Europe: Key, Host range and Phylogenetic relationship. - Zoologischer Anzeiger 243: 181209.

Mackauer, M. 1959: Die europaischen Arten der Gattungen Praon und Areopraon (Hymenoptera: Braconidae: Aphidiinae). — Beiträge zur Entomologie 9: $810-865$.

Mackauer, M. 1961: Neue europäische BlattlausSchlupfwespen (Hymenoptera: Aphidiidae). - Bollettino del Laboratoria di Entomologia Agraria "Filippo Silvestri" Portici 19: 270-290.

Mackauer, M. \& Starý, P. 1967: Hymenoptera: Ichneumonoidea, World Aphidiidae. - In Delucchi, V. \& G. Remaudičre (eds.): Index of entomophagous insects. Le Francois, Paris, 167 pp.

Matvejev, S. D. \& Puncer, I. J. 1989: (Map of biomes, landscapes of Yugoslavia and their protection.) Natural History Museum in the Belgrade, Special issue, 36, 1-76 [in Serbian].

Pennacchio, F. \& Tremblay, E. 1988: A new species of Aphidius from Italy (Hymenoptera: Braconidae: Aphidiinae). - Bollettino del Laboratoria di Entomologia Agraria "Filippo Silvestri" Portici 45: 167-169.

Sanchis, A., Michelena, J. M. \& Pujade-Villar, J. 1999: Afidiinos (Hymenoptera: Braconidae) del Pirineo Andorrano. - Boletin de la Asociación Espańola de Entomologia, 23: 239-247.

Starý, P. 1966: Aphid parasites of Czechoslovakia (The Hague: Dr. W. Junk) 247 pp.

Starý, P. 1971: New aphid parasites from Central Europe (Hymenoptera: Aphidiidae). - Acta Entomol. Bohemoslovaca $68: 310-318$.

Starý, P. 1974: Parasite spectrum (Hymenoptera: Aphi- diidae) of aphids associated with Galium - - Entomol. Scandinavica 5:73-80.

Starý, P. 1983: Parapraon, a new genus of the Aphidiidae (Hymenoptera). - Acta Entomol. Bohemoslovaca 80: 206-209.

Starý, P. \& Leclant, F. 1973: Ephedrus blattnyi sp.n. (Hymenoptera, Aphidiidae), a new parasite of Pterocomma ringdahli Wahlgr. from Czechoslovakia. Acta Entomol. Bohemoslovaca 70: 269-271.

Starý, P., Remaudiére, G. \& Leclant F. 1971: Les Aphidiidae (Hymenoptera) de France et leurs hotes (Homoptera, Aphididae). - Entomophaga, Mémoire hors série, No. 5, 72 pp.

Starý, P., Tomanović, Ž. \& Petrović, O. 1998: A new parasitoid of root-feeding aphids from the Balkan mountains (Hymenoptera: Braconidae: Aphidiinae). - Deutsche Entomologische Zeitschrift 45: 175-179.

Tomanović, Ž. \& Kavallieratos, N. G. 2002: Two new aphidiine wasps (Hymenoptera: Braconidae: Aphidiinae) from the southeastern Europe. - Reichenbachia 34: $341-345$.

Tomanović, Ž., Starý, P.\& Petrović, O. 2002: Monoctonus leclanti sp. n. (Hymenoptera: Braconidae: Aphidiinae) from highmontane areas of the southeastern Europe and key to related species. - Entomol. Fennica 13: $159-162$.

Tomanović, Ž., Kavallieratos N. G., Athanassiou C. \& Stanisavljevic, L. Ž. 2003: A review of the West Palaearctic Aphidiine (Hymenoptera: Braconidae: Aphidiinae) parasitic on Uroleucon spp. with a description of a new species. - Annales de la Societe Entomologique de France 39: 343-353.

Tomanović, Ž., Kavallieratos, N. G., Athanassiou, C. G., Petrović, O. \& Stanisavljević, L. Ž. 2004: A new Aphidius species (Hymenoptera: Braconidae: Aphidiinae) from high-montane areas of southeastern Europe. - Phytoparasitica 32: 221-225.

Trdan, S. 2002: Evaluation of morphological and genetic variability of populations of economically important thrips species (Thysanoptera) in Slovenia. Ljubljana, University of Ljubljana, Biotechnical Faculty, Department of Agronomy, Doctoral Dissertation, 90 pp. 